\title{
Ornithological observations from São Tomé and Príncipe islands (Gulf of Guinea, West Africa)
}

\author{
Pietro Lo Cascio \\ Associazione Nesos, via Vittorio Emanuele 24, 98055 Lipari (Messina), Italy; email: plocascio@nesos.org
}

\begin{abstract}
In the present paper are summarized the observations carried out on the avifauna of the islands São Tomé and Príncipe during a scientific trip. Along with a list of distributional data, remarks on population consistence and density of some endemic birds are given; among these are of particular interest those concerning the rare Dwarf Olive Ibis Bostrychia bocagei (Chapin, 1923) a threatened species for a long time considered extinct and rediscovered in 1990, currently classified as "Critically Endangered" by IUCN.
\end{abstract}

KEY WORDS Oceanic islands; avifauna distribution; endemic birds; Bostrychia bocagei; population density.

Received 15.03.2021; accepted 06.08.2021; published online 04.10.2021

\section{INTRODUCTION}

The oceanic islands of São Tomé and Príncipe in the Gulf of Guinea (West Africa, Atlantic Ocean) are included within the most Endemic Bird Areas at global level (Stattersfield et al., 1998) and the Important Bird Areas of Africa (Fishpool \& Evans, 2001). Their avifauna is characterized by an outstanding level of endemism and a remarkable species richness, reflecting its biogeographic history of isolation and radiation processes (Buchanan et al., 2011; Glor, 2011; Melo et al., 2011). The importance of adopting strong conservation measures, especially for the species living in rainforest ecosystems, has been highlighted since many years (Atkinson et al., 1991; Jones et al., 2001).

Apart from previous scattered data, the ornithological investigations on these islands started in $19^{\text {th }}$ century and have been significantly improved during the last decades (Jones \& Tye, 2006). Seventy-two breeding resident species are known on the whole for both islands (Christy \& Clarke, 1998; Jones \& Tye, 2006; Levendis \& Olmos,
2009). However, the rough morphology and the difficult to access to many inner places prevent yet the availability a good level of information, especially for the most rare and elusive species.

In February 2019, I spent four weeks on both islands and some satellite islets, carrying out field research and focusing mainly on local herpetofauna and selected groups of insects; during the trip I had however the opportunity to record 41 bird species on the whole (40 resident breeding, equal to $51 \%$ of the occurring species, and 1 migrant) as well to make some observations on endemic and/or interesting birds that are summarized in this paper.

\section{MATERIAL AND METHODS}

\section{Study area}

The islands of São Tomé $\left(00^{\circ} 01^{\prime} \mathrm{S}-00^{\circ} 24^{\prime} \mathrm{N}\right.$, $\left.06^{\circ} 27^{\prime}-06^{\circ} 45^{\prime} \mathrm{E}\right)$ and Príncipe $\left(01^{\circ} 32^{\prime}-01^{\circ} 43^{\prime} \mathrm{N}\right.$, $07^{\circ} 20^{\prime}-07^{\circ} 28^{\prime}$ E) lie in the Gulf of Guinea, more than $200 \mathrm{~km}$ off the western African coast, and be- 
long to the Democratic Republic of São Tomé and Príncipe. The first is the largest of the group, with a surface of $857 \mathrm{~km}^{2}$ and a maximum elevation of $2,024 \mathrm{~m}$ a.s.l. (at Pico São Tomé); Príncipe has a surface of $137 \mathrm{~km}^{2}$ and reaches its maximum elevation at $948 \mathrm{~m}$ a.s.l. (Pico do Príncipe). Both were uninhabited when have been discovered by Portuguese in late $15^{\text {th }}$ century, but in few decades become an important center for slave trade and for the production of tropical crops (sugar, cocoa and coffee). Currently, São Tomé is heavily populated, with densities of $>100$ people $/ \mathrm{km}^{2}$ and more than 170,000 inhabitants, mostly concentrated in the north-eastern sector, while Príncipe has only 6,000 inhabitants, mostly living in the main town.

Their emersion is related to the Tertiary volcanic activity of the Cameroon Line and is dated about 31 million years (Ma) ago for Príncipe and $13 \mathrm{Ma}$ for São Tomé; however, on this latter volcanic activity occurred until $0,08-0,03 \mathrm{Ma}$, while the last phase of formation of Príncipe is dated about 3,5 Ma (Lee et al., 1994; Barfod \& Fitton, 2014).

The islands' mountain reliefs intercepts the prevailing moist southwesterly winds throughout the year, and the rainfall is higher in the south-west sector $(7,000$ and $5,000 \mathrm{~mm} /$ year, respectively, in São Tomé and Príncipe); in the extreme north of São Tomé, however, it may be as little as $600 \mathrm{~mm}$ per year. The rainy season is from September to May, while a driest period (known as gravana) occurs in July-August. Usually there is also a short dry period between December and February (gravanito). At sealevel the daily temperature is $22-33^{\circ} \mathrm{C}$ and the mean humidity of $80 \%$; at higher altitude, over $800 \mathrm{~m}$ a.s.l., the absolute minimum is around $9{ }^{\circ} \mathrm{C}$ (Bredero et al., 1977). Especially on São Tomé, the insolation is low (1,5-3,5 hours per day) due to the constant presence of cloud formations in the center of the island.

The most accessible areas of these islands undergone strong deforestation due to agricultural exploitation, but the collapse in the economic value of the plantations' production since the 1930s has resulted in significant regeneration of shade or secondary forest, whose boundaries are sometime difficult to be distinguished from the native formations (Carvalho et al., 2004). However, during the last decades the expansion of palm oil cultivations poses a serious threat to local biodiversity (Barros, 2003). The primary rainforests (locally known as obó) currently cover $29 \%$ and $25 \%$ of the surface, respectively, of Príncipe and São Tomé. On this latter are usually recognized three main zones: Lowland (extending from sea-level to $800-1,000 \mathrm{~m}$ a.s.1.), ii) Highland (between 1,000 and 1,800 m) and iii) Montane and Mist forest (over 1,800 m), where temperature are low and light is strongly reduced by mist (Figueiredo et al., 2011). On Príncipe, only towards the highest reliefs the forest assumes instead a slightly montane character, but the altitude is too low to support the same differentiation occurring within the forest ecosystems of São Tomé.

\section{RESULTS}

\section{Ornithological observations}

In Table 1 are listed the sites where have been carried out field-surveys, with their main geographical and ecological data; their localization is given in Fig. 1. The surveys were generally done during the walks or the breaks; however, some selected areas have been choose to perform transects, with 10 minutes-stop each $100 \mathrm{~m}$ during which the identity of the species and number of individuals was recorded; this method allows to minimizes the bias associated with bird moving in response to the observer and to detect also more cryptic or elusive species. Field work was made by using a Kite "Pe-

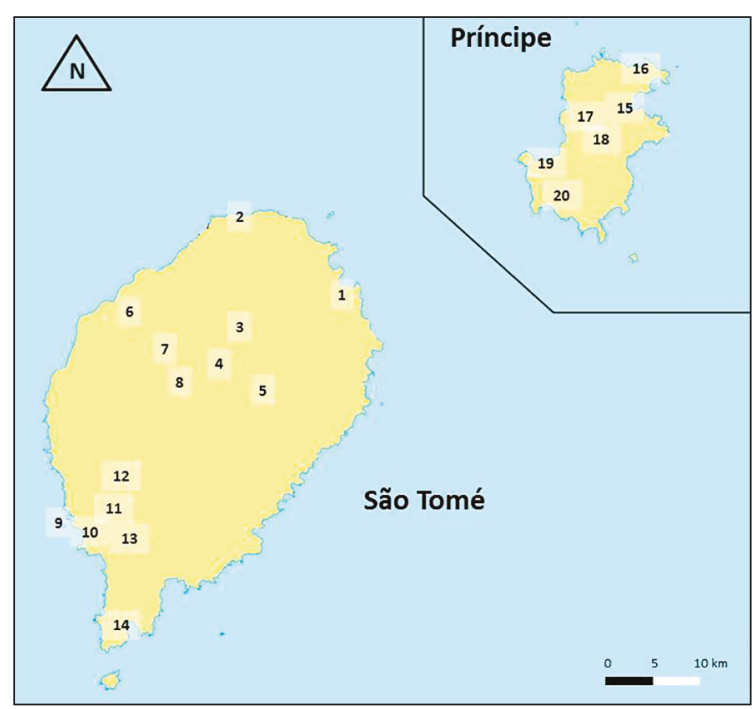

Figure 1. Localization of the sites of field-surveys. 


\begin{tabular}{|c|c|c|c|c|}
\hline & & localization & $\begin{array}{l}\text { elevation } \\
\text { (m a.s.l.) }\end{array}$ & habitat \\
\hline \multicolumn{5}{|c|}{ SÃO TOMÉ ISLAND } \\
\hline 1 & São Tomé & $0^{\circ} 19^{\prime} 44^{\prime \prime} \mathrm{N}, 6^{\circ} 44^{\prime} 22^{\prime \prime} \mathrm{E}$ & $0-50$ & town \\
\hline 2 & Morro Peixe/Lagoa Azul & $0^{\circ} 24^{\prime} 16^{\prime \prime} \mathrm{N}, 6^{\circ} 37^{\prime} 04^{\prime \prime} \mathrm{E}$ & $0-50$ & savannah/tidal marshes \\
\hline 3 & surrounding Monte Café & $0^{\circ} 18^{\prime} 16^{\prime \prime} \mathrm{N}, 6^{\circ} 38^{\prime} 11^{\prime \prime} \mathrm{E}$ & $670-850$ & shade forest/plantations \\
\hline 4 & Lagoa Amélia & $0^{\circ} 16^{\prime} 55^{\prime \prime} \mathrm{N}, 6^{\circ} 35^{\prime} 28^{\prime \prime} \mathrm{E}$ & $1300-1400$ & highland/montane forest \\
\hline 5 & surrounding Bombaim & $0^{\circ} 14^{\prime} 44^{\prime \prime} \mathrm{N}, 6^{\circ} 37^{\prime} 56^{\prime \prime} \mathrm{E}$ & $470-550$ & secondary/lowland forest \\
\hline 6 & Monte Careca & $0^{\circ} 19^{\prime} 43^{\prime \prime} \mathrm{N}, 6^{\circ} 32^{\prime} 22^{\prime \prime} \mathrm{E}$ & 250 & shade/secondary forest \\
\hline 7 & Manuel Morais/Cascada Angolar & $0^{\circ} 17^{\prime} 40^{\prime \prime} \mathrm{N}, 6^{\circ} 34^{\prime} 13^{\prime \prime} \mathrm{E}$ & $570-930$ & secondary/highland forest \\
\hline 8 & surrounding Pico Calvario & $0^{\circ} 16^{\prime} 02^{\prime \prime} \mathrm{N}, 6^{\circ} 34^{\prime} 40^{\prime \prime} \mathrm{E}$ & $1350-1450$ & montane forest \\
\hline 9 & Ilhéus São Miguel/Ilhéus Gabado & $0^{\circ} 08^{\prime} 04^{\prime \prime} \mathrm{N}, 6^{\circ} 28^{\prime} 55^{\prime \prime} \mathrm{E}$ & 0 & rocky shores \\
\hline 10 & Praia Pipa & $0^{\circ} 07^{\prime} 42^{\prime \prime} \mathrm{N}, 6^{\circ} 29^{\prime} 43^{\prime \prime} \mathrm{E}$ & $0-100$ & sandy beach, lowland forest \\
\hline 11 & Rio Xufexufe 1 & $0^{\circ} 09^{\prime} 26^{\prime \prime} \mathrm{N}, 6^{\circ} 30^{\prime} 38^{\prime \prime} \mathrm{E}$ & $130-150$ & lowland forest \\
\hline 12 & Rio Xufexufe 2 & $0^{\circ} 11^{\prime} 31^{\prime \prime} \mathrm{N}, 6^{\circ} 32^{\prime} 34^{\prime \prime} \mathrm{E}$ & $350-400$ & lowland forest \\
\hline 13 & Rio Quijia & $0^{\circ} 09^{\prime} 08^{\prime \prime} \mathrm{N}, 6^{\circ} 32^{\prime} 14^{\prime \prime} \mathrm{E}$ & $350-400$ & lowland forest \\
\hline 14 & Malanza & $0^{\circ} 02^{\prime} 45^{\prime \prime} \mathrm{N}, 6^{\circ} 31^{\prime} 46^{\prime \prime} \mathrm{E}$ & 0 & mangroves \\
\hline \multicolumn{5}{|c|}{ PRÍNCIPE ISLAND } \\
\hline 15 & Santo António/Rio Papagayo & $1^{\circ} 38^{\prime} 08^{\prime \prime} \mathrm{N}, 7^{\circ} 25^{\prime} 07^{\prime \prime} \mathrm{E}$ & $0-30$ & town, sandy beach, river \\
\hline 16 & Praia S. Rita/Praia das Burras & $1^{\circ} 40^{\prime} 52^{\prime \prime} \mathrm{N}, 7^{\circ} 26^{\prime} 24^{\prime \prime} \mathrm{E}$ & $0-130$ & sandy beach, shade forest \\
\hline 17 & S. Joaquim/Montalegre & $1^{\circ} 40^{\prime} 02^{\prime \prime} \mathrm{N}, 7^{\circ} 22^{\prime} 52^{\prime \prime} \mathrm{E}$ & 150 & secondary forest/plantations \\
\hline 18 & Pico Papagaio & $1^{\circ} 36^{\prime} 40^{\prime \prime} \mathrm{N}, 7^{\circ} 23^{\prime} 35^{\prime \prime} \mathrm{E}$ & $600-680$ & highland forest \\
\hline 19 & Rio de Agulhas & $1^{\circ} 36^{\prime} 00^{\prime \prime} \mathrm{N}, 7^{\circ} 21^{\prime} 33^{\prime \prime} \mathrm{E}$ & $0-50$ & river, lowland forest \\
\hline 20 & Ribeira da São Tomé & $1^{\circ} 33^{\prime} 43^{\prime \prime} \mathrm{N}, 7^{\circ} 21^{\prime} 23^{\prime \prime} \mathrm{E}$ & $0-50$ & river, lowland forest \\
\hline
\end{tabular}

Table 1. Geographical and ecological data of the field-survey sites.

trel" 10x40 binoculars, while photos were taken with a Canon EOS 760D camera equipped with zoom lens Tamron SP 150-600 mm.

In Table 2 are given distributional data for 41 bird species recorded during the trip. The species list follows the systematic order of the checklist of Jones \& Tye (2006), while taxonomic and nomenclatural treatment have been updated according to Avibase (https://avibase.bsc-eoc.org) and references therein, except for the members of the family Ploceidae (see De Silva et al., 2017; 2019). Some remarks concerning the most interesting species are instead provided in detail below.

\section{Ascension White-tailed Tropicbird}

Phaethon lepturus ascensionis Mathew, 1915 (Fig. 2)

Pantropical species, in Atlantic Ocean represented by the ssp. ascensionis. Recorded as breeding species on coastal cliffs of São Tomé, Príncipe and especially on satellite islets (Cabras, Rolas, Santana, Quixiba, Sete Pedras, Caroço (or Boné do Jóquei), Bonézinho, Monsteiros), where it avoids eggs harvesting from humans and predation risk from the introduced Mona monkeys Cercopithecus mona (Jones \& Tye, 2006; Bollen et al., 2018).

The observation of two adults flying alongside of the cliff and one in a rock crevice on the top of Ilhéu Gabado (Fig. 3), not far from the SW coast of São Tomé, suggest the occurrence of a small breeding colony also on this islet, previously unrecorded.

\section{Dwarf Olive Ibis \\ Bostrychia bocagei (Chapin, 1923) (Fig. 4)}

Dwarf Olive Ibis is one of the world's most rare and threatened birds, classified as Critically Endangered (IUCN, 2021; BirdLife International, 2021). Discovered in the late 1880 s by the Portuguese collector Francisco Newton, it was initially known from a few collected specimens and from some sightings reported by local hunters, until its last record in 1928 (Collar \& Stuart, 1985; Jones \& Tye, 2006). After this date, it was considered extinct until its rediscovery in 1990 (Atkinson et al., 1991). Currently this endemic species seems to be confined only in an area of about $210 \mathrm{~km}^{2}$ of the central and southern part of the island and its consistence has been theoretically 


\begin{tabular}{|c|c|c|}
\hline SPECIES & Status & SITE \\
\hline White-tailed tropicbird Phaeton lepturus ascensionis Mathew, 1915 & $\mathrm{RB}$ & 9,16 \\
\hline Reed Cormorant Phalacrocorax africanus (Gmelin, 1789) & $\mathrm{RB}$ & $2,14,19$ \\
\hline Cattle Egret Bubulcus ibis (L., 1758) & $\mathrm{RB}$ & $4,5,16,17$ \\
\hline Western Reef Heron Egretta gularis (Bosc, 1792) & $\mathrm{RB}$ & 2 \\
\hline Dwarf Ibis Bostrychia bocagei Chapin, 1923 & $\mathrm{E}$ & $10,11,12,13$ \\
\hline Yellow-billed Kite Milvus [aegyptius] parasitus (Daudin, 1800) & $\mathrm{RB}$ & $2,4,5,6,7,8,10,14,15$ \\
\hline Common Moorhen Gallinula chloropus (L., 1758) & $\mathrm{RB}$ & 2 \\
\hline Whimbrel Numenius phaeopus (L., 1758) & M & 19 \\
\hline African Green Pigeon Treron calvus virescens Amadon, 1953 & $\mathrm{E}(\mathrm{ssp})$ & 18 \\
\hline São Tomé Green Pigeon Treron sanctithomeae (Gmelin, 1789) & $\mathrm{E}$ & 3,5 \\
\hline São Tomé Bronze-naped Pigeon Columba malherbii Verreaux \& Verreaux, 1851 & $\mathrm{E}$ & $3,4,17$ \\
\hline Lemon Dove Columba larvata simplex (Hartlaub, 1849) & E (ssp) & 6 \\
\hline Maroon Pigeon Columba thomensis Bocage, 1888 & $\mathrm{E}$ & $4,7,12$ \\
\hline Rock Dove Columba livia Gmelin, 1789 & $\mathrm{RB}$ & 1 \\
\hline Laughing Dove Streptopelia senegalensis (L., 1766) & $\mathrm{RB}$ & $1,15,16$ \\
\hline Grey Parrot Psittacus erithacus L., 1758 & $\mathrm{RB}$ & 17,20 \\
\hline Barn owl Tyto alba thomensis (Hartlaub, 1852) & E (ssp) & 5,12 \\
\hline São Tomé Spinetail Zoonavena thomensis (Hartert, 1900) & $\mathrm{E}$ & $3,4,14$ \\
\hline Blue-breasted Kingfisher Halcyon malimbica dryas Hartlaub, 1854 & $\mathrm{E}(\mathrm{ssp})$ & $15,16,19,20$ \\
\hline Príncipe Malachite Kingfisher Alcedo cristata nais (Kaup, 1848) & $\mathrm{E}(\mathrm{ssp})$ & $15,19,20$ \\
\hline São Tomé Malachite Kingfisher Alcedo cristata thomensis (Salvadori, 1902) & E (ssp) & $6,10,14$ \\
\hline São Tomé Trush Turdus olivaceofuscus Hartlaub, 1852 & $\mathrm{E}(\mathrm{ssp})$ & 6 \\
\hline São Tomé Prinia Prinia molleri Bocage, 1887 & $\mathrm{E}$ & $1,3,4,5,6,7,10,13,14$ \\
\hline São Tomé Short-tail Motacilla bocagii (Sharpe, 1892) & $\mathrm{E}$ & 10 \\
\hline São Tomé Paradise Flycatcher Terpsiphone atrochalybeia (Thomson, 1842) & $\mathrm{E}$ & 3 \\
\hline Newton Sunbird Anabathmis newtonii Bocage, 1887 & $\mathrm{E}$ & $3,6,8,10,12$ \\
\hline Príncipe Sunbird Anabathmis hartlaubii (Hartlaub, 1857) & $\mathrm{E}$ & 19,20 \\
\hline Olive Sunbird Cyanomitra olivacea (Smith, 1840) & $\mathrm{RB}$ & $16,17,20$ \\
\hline Black-capped Speirops Zosterops lugubris Hartlaub, 1848 & $\mathrm{E}$ & 3,6 \\
\hline São Tomé Oriole Oriolus crassirostris Hartlaub, 1857 & $\mathrm{E}$ & 4,8 \\
\hline Splendid Glossy Starling Lamprotornis splendidus (Vieillot, 1822) & $\mathrm{RB}$ & 17,19 \\
\hline Príncipe Golden Weaver Malimbus princeps (Bonaparte, 1850) & $\mathrm{E}$ & $16,17,18,19,20$ \\
\hline Vitelline Masked Weaver Malimbus velatus peixotoi (Frade \& Naurois, 1964) & E (ssp) & 2 \\
\hline São Tomé Weaver Malimbus sanctithomae (Hartlaub, 1848) & $\mathrm{E}$ & 2 \\
\hline Fire-crowned Bishop Euplectes hordeaceus (L., 1758) & $\mathrm{RB}$ & 2 \\
\hline Golden-backed Bishop Euplectes aureus (Gmelin, 1789) & $\mathrm{RB}$ & 2 \\
\hline White.winged Widowbird Euplectes albonotatus (Cassin, 1848) & $\mathrm{RB}$ & 1,2 \\
\hline Common Waxbill Estrilda astrild (L., 1758) & $\mathrm{RB}$ & $3,5,6,16$ \\
\hline Blue-breasted Cordon-bleu Uraeginthus angolensis (L., 1758) & $\mathrm{RB}$ & $1,2,6,14$ \\
\hline Yellow-fronted Canary Crithagra mozambica (Müller, 1776) & $\mathrm{RB}$ & 1 \\
\hline
\end{tabular}

Table 2. Distributional data for the bird species observed in the islands of São Tomé and Príncipe. E: narrow endemic species (or subspecies); RB: resident breeding; M: migrant. 
estimated as $>2000$ individuals by using a Density Surface Modelling (see Pereira Azevedo, 2015).

During the trip, I spent four days in the primary lowland forest that covers the catchments of Rio Xufexufe (Fig. 5) and Rio Quijia, in the south-western part of the island. The weather was almost always rainy, a condition that along with the low light often prevented to obtain good photographic material. The first day I found two small areas with loose soil, droppings and tracks, where one or more ibises must have recently foraged (site 10). The first sighting, although from a considerable distance, took place on the second day at site 11: a group of seven individuals perched on low branches. On the third day at site 12 , first a single and then a group of three individuals were always observed on tree branches, as well as other traces of foraging; during the approach to these latter it was possible to heard for the first time the call, likely emitted as a disturbing signal. Finally, the fourth day in site 13 it was possible to see another individual and, at sunset, to heard other calls.

Considering an average of 5-6 hours per day of field survey, the encounter rate was from 0.2 to 1.4 individual/hour. The daily walks ranged from 1 to $3 \mathrm{~km}$, but cannot be considered as linear transects due to the difficulty of moving in the rainforest, so it is not possible to reliably estimate the density of the species in the explored area. However, at least 12 individuals (not counting the calls) seen during a 4 days-survey within a total surface not larger than $10 \mathrm{~km}^{2}$ suggest a relatively high abundance, if compared with the consistence recorded by Maia et al. (2014). The Dwarf Olive Ibis seems to be more common in forest environments over $100 \mathrm{~m}$ a.s.l., although some traces have been found also at lower altitude, not far from the mouth of Rio Xufexufe. Its habitat seems rather undisturbed in this area of São Tomé (included in the boundaries of the National Park Obó), but the nearby presence of small settlements of palm wine collectors (locally known as vianteiros) at Praia Pipa could represent a potential risk for the ibises, that unfortunately are still hunted by locals (Dallimer et al., 2009).

\section{African Yellow-billed Kite}

Milvus [aegyptius] parasitus (Daudin, 1800) (Fig. 6)

The taxonomic status of the Kite from São Tomé, for a long time referred to Milvus migrans Boddaert, 1783 (see Jones \& Tye, 2006) and more recently to

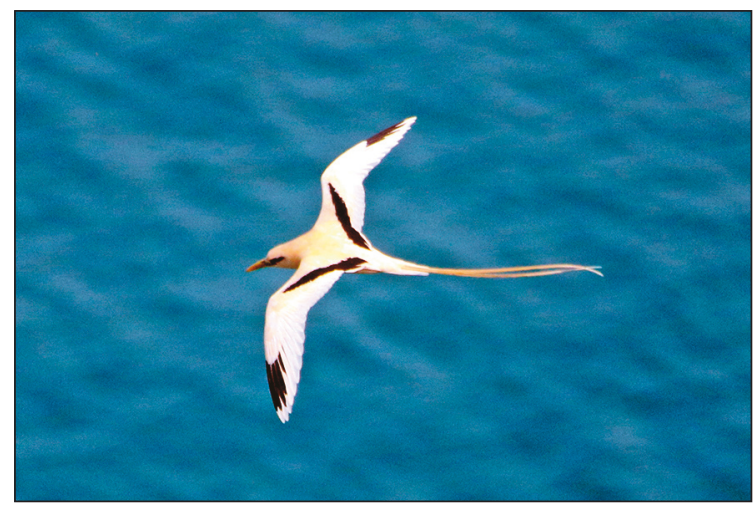

Figure 2. Ascension White-tailed Tropicbird Phaethon lepturus ssp. ascensionis.

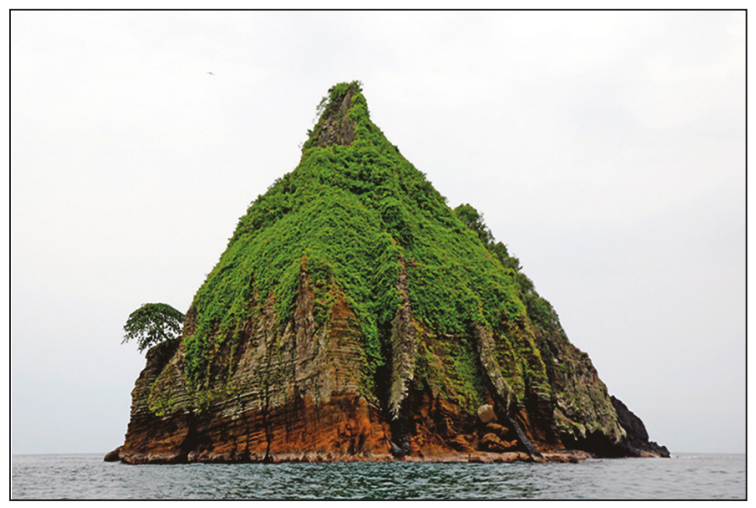

Figure 3. Ilhéu Gabado, off the SW coast of São Tomé, where occurs a small number of breeding pairs of Phaeton lepturus.

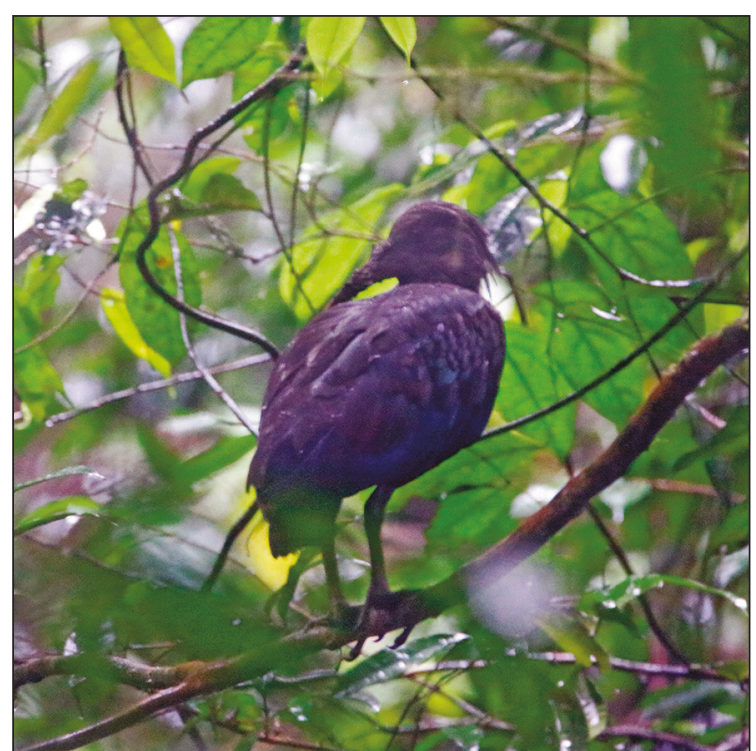

Figure 4. Dwarf Olive Ibis Bostrychia bocagei, a rare and threatened endemic of São Tomé. 


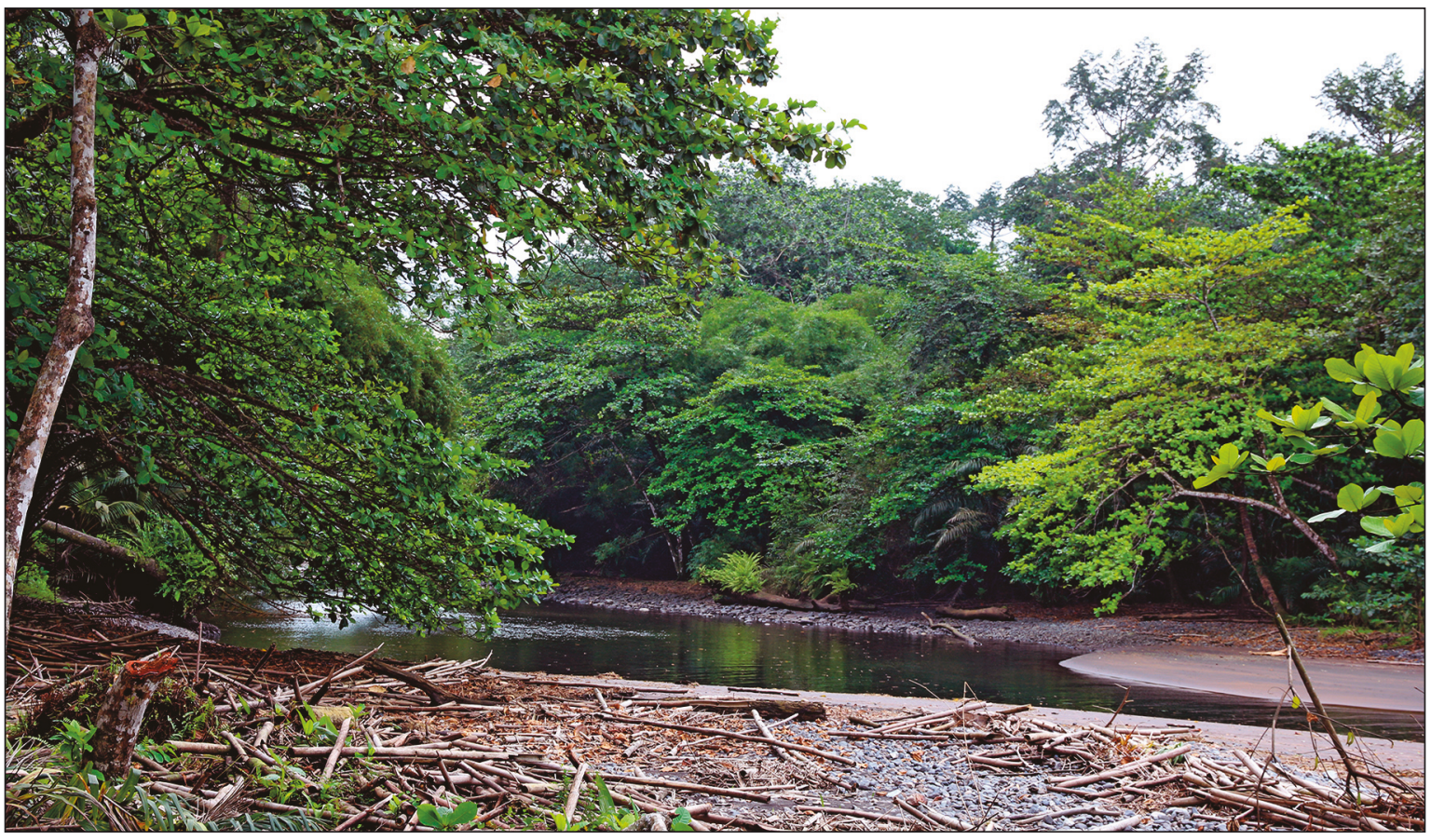

Figure 5. The lowland forest nearby the mouth of Rio Xufexufe, São Tomé.

the sub-Saharan subspecies parasitus (see Leventis \& Olmos, 2009), must be reconsidered in the light of the recent revaluation of M. migrans aegyptius (Gmelin, 1788) as a full species (Johnson et al., 2005); parasitus is in fact treated as subspecies of this latter (see at https://avibase.bsc-eoc.org) or even should be a separate species, on the basis of the differences found between mitochondrial haplotypes of their populations (Andreyenkova et al., 2019).

I have only seen it once at Príncipe (in the Santo António Bay, near the main town), while it seems relatively common throughout the island of São Tomé, where occurs in many habitats and also at high altitudes. A rather unusual behavior for a raptor species was observed on the northern coast, where I have repeatedly seen large groups of these birds (up to 18 individuals) following the fishermen's canoes in search of food, therefore adopting a foraging strategy typical of the gulls (which instead are completely absent here) and other seabirds. The same was previously observed by Sargeant (1994), and it is likely that here the diet of the species could be strongly dependent from fisheries and mainly based on discarded fishes. A high rate of fish consumption by the African Yellow-billed Kite has been also documented by Habib et al. (2018) for coastal areas of Egypt.

\section{Blue-breasted Kingfisher \\ Halcyon malimbica ssp. dryas Hartlaub, 1854 (Fig. 7)}

This subspecies is considered as a narrow endemic of Príncipe, after Jones \& Tye (2006) have clarified that records for São Tomé or other localities are not reliable.

The Blue-breasted kingfisher seems to be fair common in the south-western sector of the island (sites 19 and 20), in particular along Ribeira de São Tomé where in two hours I counted 9 individuals going up the shores of the river for about $1 \mathrm{~km}$. For the same area Dallimer \& King (2007) have estimated a density of 0.19 individuals per hectare.

\section{Príncipe Malachite Kingfisher Alcedo cristata ssp. nais (Kaup, 1848) (Fig. 8)}

Endemic subspecies of Príncipe (Melo \& Fuchs, 2008), considered relatively common throughout the island (Jones \& Tye, 2006). In the forests of the SW sector of the island, Dallimer \& King (2007) found a density of 0.02 individuals per hectare.

During the present research, linear transects of $500 \mathrm{~m}$ carried out in two different areas, namely sites 15 and 19, provided density estimates respec- 
tively equal to 1.2 and 0.4 individuals $/ 100 \mathrm{~m}$. Unexpectedly, the frequency of this species resulted to be higher in a more strongly anthropized and disturbed site (Rio Papagayo, near the urban center of Santo António) than in natural habitats occupied by coastal vegetation and lowland forest, where also there is a stream (Rio de Agulhas). This pattern, which has some analogies to that observed for Malimbus princeps (see below), suggests as the endemic species of Príncipe are able to adapt well to altered environments and even to be dominant, at least as much as in native habitats. These observations are apparently in contrast to the general assumption that high levels of extinction on islands reflect a lower adaptive potential of island species compared to their continental relatives
(Whittaker \& Fernández-Palacios, 2007; Gillespie et al. 2008).

However, it should be noted that environmental alterations are not particularly severe in Príncipe, where the more drastic human interventions occurred some centuries ago (Dallimer et al., 2012), thus during this time span the endemic birds may have developed a certain degree of resilience.

\section{São Tomé Prinia \\ Prinia molleri Bocage, 1887 (Fig. 9)}

Endemic of São Tomé, this species is locally known as "troqui" or "truqui", an onomatopoeic name inspired by its typical wingbeats sound associated to the call during its short and frequent aerial
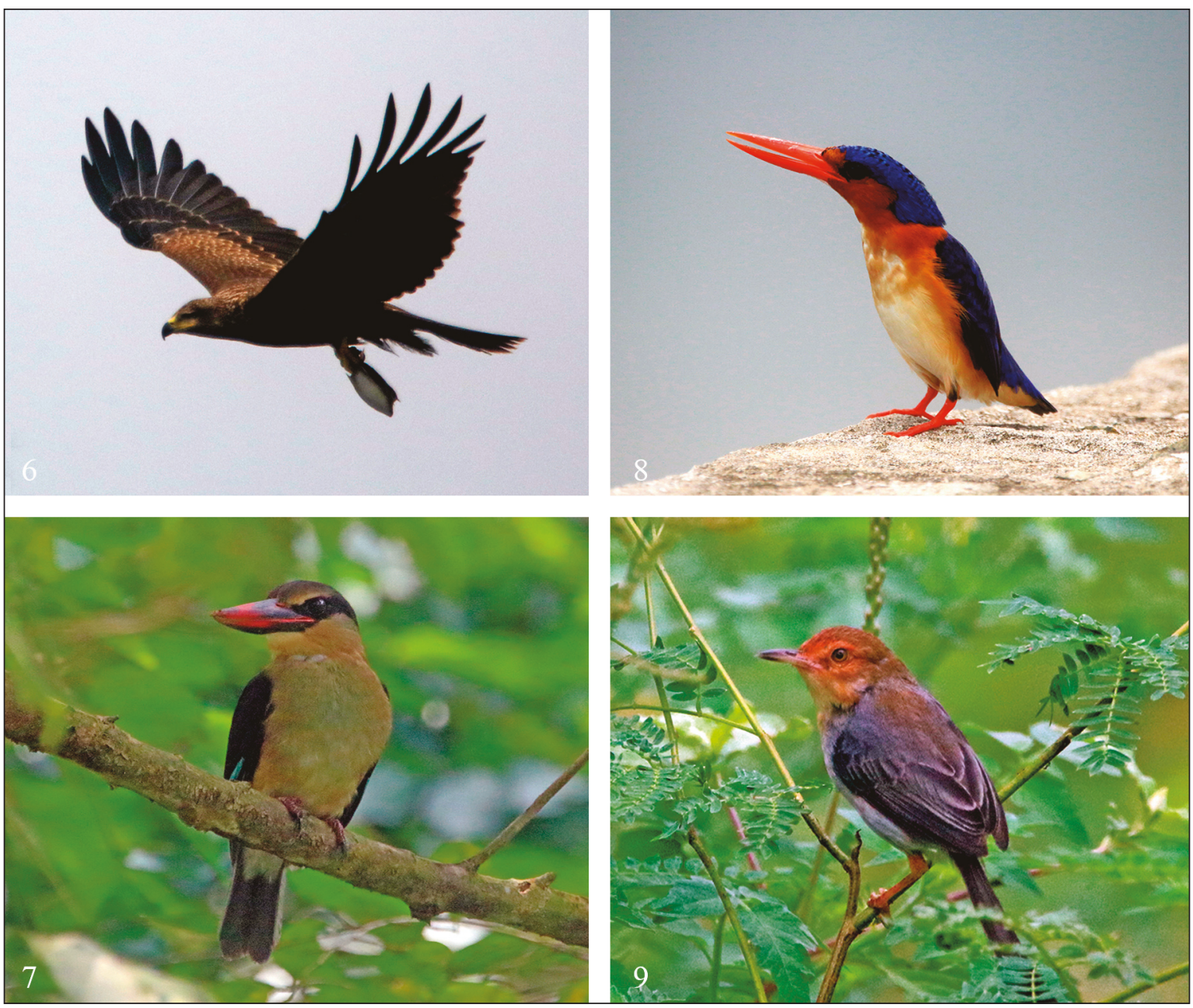

Figure 6. African Yellow-billed kite Milvus [aegyptius] parasitus with a fish prey. Figure 7. Blue-breasted Kingfisher Halcyon malimbica ssp. dryas, endemic of Príncipe. Figure 8. White-bellied Kingfisher Alcedo cristata ssp. nais, endemic of Príncipe. Figure 9. São Tomé Prinia Prinia molleri, endemic of São Tomé. 
displays. According to Jones \& Tye (2006), it is more abundant in open habitats and forest edges than in primary forests.

During my trip, I found the species in the most part of the visited sites (9 out of 14), and it was apparently lacking just from the dense highland/montane and the inner lowland forest of the W and SW sectors of the island. I have seen often one/more adults in small groups with young, while only two times adults that probably were feeding nestlings; in February, hence, most part of its populations have probably ultimate the reproductive season. Fledglings are more yellowish in the breast and in the throat than adults, and their iris is grey instead than brown. The diet is basically insectivore, but may include also Erythrina flowers and vegetal matter (Naurois, 1984; Jones \& Tye, 2006; Levendis \& Olmos, 2009). I have observed often adults digging in rotting trunks, perhaps in search of termites or larvae of beetles; also, I saw in one occasion some birds hunting insects around the bowls placed by the vianteiros on the palm trees to collect sap, where the smell of fermentation is very attractive for several Coleoptera (especially Scarabaeidae) and Diptera.

Two linear transects of $500 \mathrm{~m}$ in site 5 (plantations and shade forest near Bombaim, in the center of the island) provided density estimate of 2.4-3 individuals $/ 100 \mathrm{~m}$. From another linear transect, performed in the plantations near Monte Careca (site 6 , western sector), has resulted a higher value ( 4.2 ind./100 m). In both sites, however, density could be underestimated, because from the counting have been excluded the records based only on calls.

\section{Príncipe Golden Weaver \\ Malimbus princeps (Bonaparte, 1850)}

Endemic of Príncipe and the nearby Ilheu Caroço (Boné do Jóquei), this species was placed for a long-time in the genus Ploceus until the recent phylogenetic study of De Silva et al. (2017; 2019). It seems abundant in all habitats but less common in dense hill forest, where Dallimer \& King (2007) found a density of just 0.33 individuals per hectare.

The species was recorded in all the visited sites throughout the island, but with an higher occurrence in the plantations (rocas) of the northern and central sector. Around Roca Belo Monte, a wide private garden hosts the larger population I have seen in the island (about 14-18 individuals per hectare); here the weavers nest almost exclusively on the introduced palm trees. As commonly observed for other species of weavers (Crook, 1964), the interactions among conspecifics seem to be characterized by a strong territoriality: during 5 minutes of constant observation of an individual who was foraging on palm drupes, he exhibited aggressive behavior towards other birds who attempted to access the same fruits at least 6 times (Fig. 10). The species is indeed basically insectivore but its diet includes several fruits and pollen (Atkinson et al., 1994; Craig, 2014).

\section{ACKNOWLEDGEMENTS}

I wish to express my gratitude to Tiziano Pisoni and the staff of Mucumbli Explore for their valuable logistical support during the trip. Scientific investigations have been carried out with the permission of Direcção Geral do Ambiente, Ministério das Obras Públicas, Infraestruturas, Recursos naturais e Ambiente of the Democratic Republic of São Tomé and Príncipe (authorization MIRNA-DGA/22/2019).

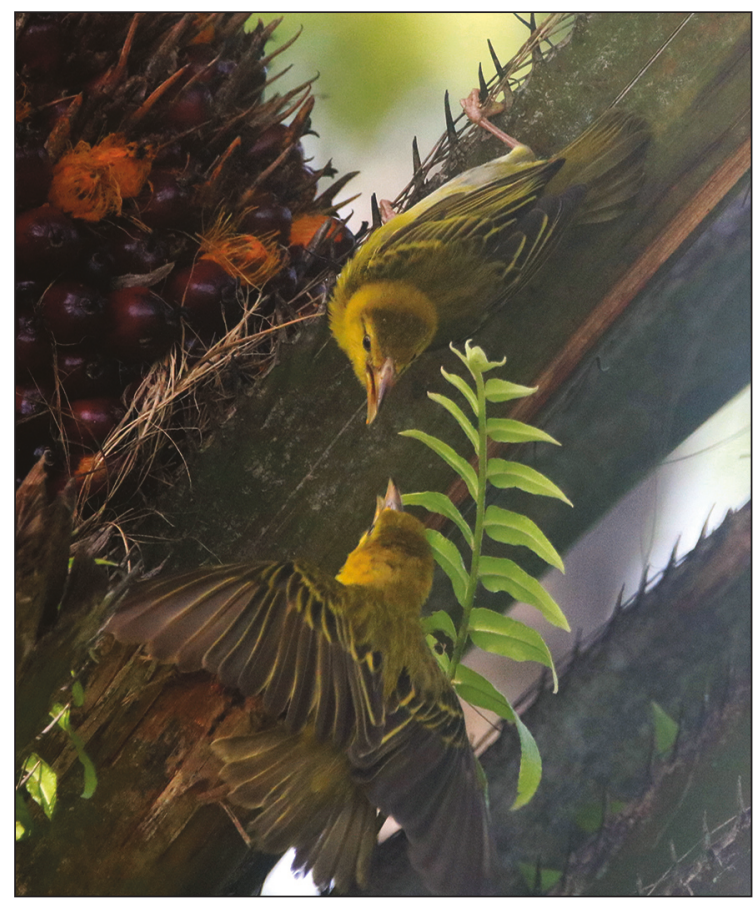

Figure 10. Two adults of the endemic Príncipe Golden Weaver Malimbus princeps displaying a territorial behaviour nearby the food sources. 

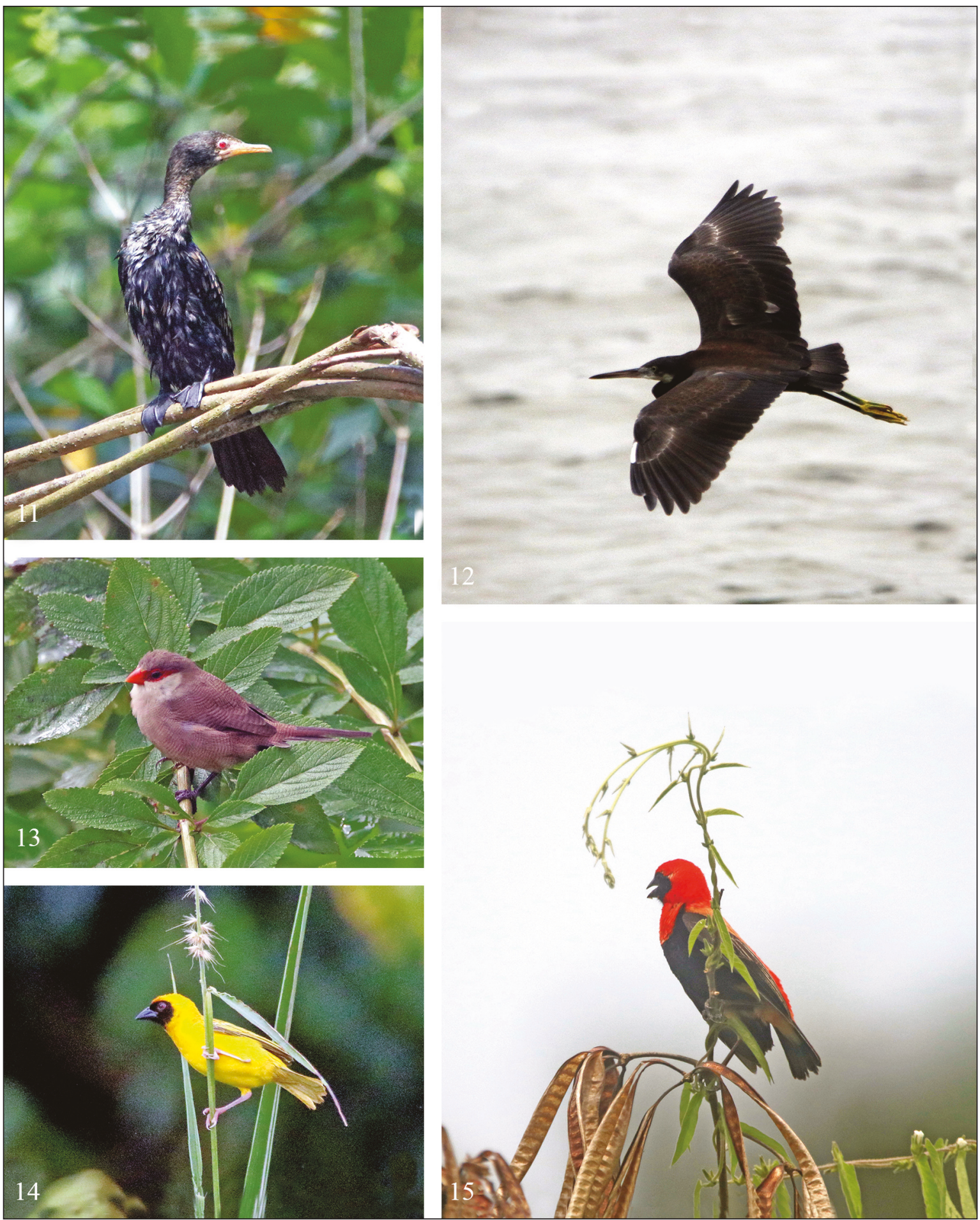

Figures 11-15. Other birds from São Tomé. Fig. 11: Reed Cormorant Phalacrocorax africanus in the Malanza mangroves. Fig. 12: Western Reef Heron Egretta gularis in the northern coast. Fig. 13: The Common Waxbill Estrilda astrild is widespread in Africa and invasive in Europe and South America. Fig. 14: The Vitelline Masked Weaver Malimbus velatus was seen firstly in the 1920s; the local population is however represented by an endemic race (peixotoi), whose fast differentiation may reflects a founder effect deriving from a small initial gene pool. Fig. 15: The Fire-crowned Bishop Euplectes hordeaceus was observed since late $19^{\text {th }}$ century and belongs to the stock of new colonizers, mainly grain-eating, related with the occurrence of open and disturbed areas. 


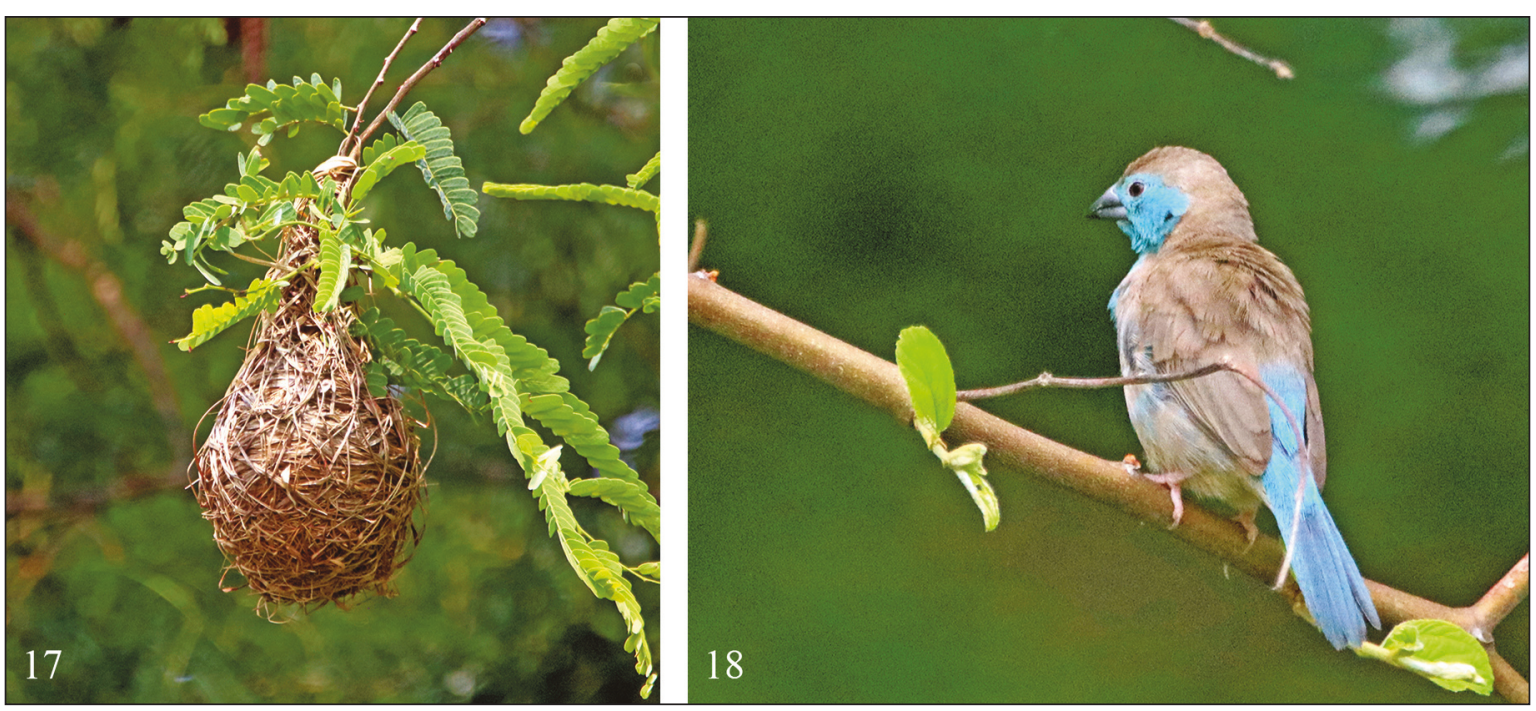

Figures 17, 18. Other birds from São Tomé. Fig. 17: Pear-shaped nest of Malimbus velatus peixotoi. Fig. 18: The Bluebreasted Cordon-bleu Uraeginthus angolensis is the most common species in urban environments and plantations.

\section{REFERENCES}

Andreyenkova N.G., Starikov I.J., Wink M., Karyakin I.V., Andreyenkov O.V. \& Zhimulev I.F., 2019. The problems of genetic support of dividing the black kite (Milvus migrans) into subspecies. Vavilovskii Zhurnal Genetiki i Selektsii, 23: 226-231.

Atkinson P.W., Peet N.B. \& Alexander J., 1991. The status and conservation of the endemic bird species of São Tomé and Príncipe, West Africa. Bird Conservation International, 1: 255-282.

Atkinson P.W., Dutton J.S., Peet N.B. \& Sequeira V. (eds.), 1994. A study of the birds, small mammals, turtles and medicinal plants of São Tomé with notes on Príncipe. Study Report 56, BirdLife International, Cambridge.

Barfod D.N. \& Fitton J.G., 2014. Pleistocene volcanism on São Tomé, Gulf of Guinea, West Africa. Quaternary Geochronology, 21: 77-89.

Barros N., 2013. Mapping a palm oil company's effect on local biodiversity in São Tomé and Príncipe. BirdLife Africa Newsletter, 13: 13.

BirdLife International, 2014. International Species Action Plan for the Conservation of Critically Endangered birds on São Tomé, 2014-2018. On-line at: https://www.birdlife.org [last access: 07/03/2021]

BirdLife International, 2021. Species factsheet: Bostrychia bocagei. On-line at: https://www.birdlife.org [last access: 07/03/2021]

Bollen A., Matilde E. \& Barros N., 2018. An updated assessment of the seabird populations breeding at Príncipe and Tinhosas. Ostrich, 89: 47-58.

Bredero J.T., Heemskerk W. \& Toxopeus H., 1977. Agri- culture and livestock production in São Tomé and Príncipe (West Africa). Foundation for Agricultural Plant Breeding, Wageningen.

Buchanan G.M., Donald P.F. \& Butchart S.H.M., 2011. Identifying priority areas for conservation: a global assessment for forest-dependent birds. PLoS One, 6(1): e29080

Carvalho S., de Oliveira F. \& Vaz H., 2004. Situation des ressources génétiques forestières de la République Démocratique de São Tomé-et-Príncipe. Division des Ressources Forestières - FAO, Rome, http://www.fao.org/3/j2109f/j2109f00.htm.

Christy P. \& Clarke W.V., 1998. Guide des oiseaux de São Tomé et Príncipe. ECOFAC, São Tomé.

Figueiredo E., Paiva J., Stévart T., Oliveira F. \& Smith G.F., 2011. Annotated catalogue of the flowering plants of São Tomé and Príncipe. Bothalia, 41: 4182.

Collar N.J. \& Stuart S.N., 1985. Threatened Birds of Africa and related islands. ICBP-IUCN, Cambridge.

Craig A.J.F.K., 2014. Nectar feeding by weavers (Ploceidae) and their role as pollinators. Journal of African Ornithology, 85: 25-30.

Crook J.H., 1964. The evolution of social organisation and visual communication in the Weaver birds (Ploceinae). Behaviour, suppl. 1964: 1-201.

Dallimer M. \& King T., 2007. Habitat preferences of the forest birds on the island of Príncipe, Gulf of Guinea. African Journal of Ecology, 46: 258-266.

Dallimer M., King T. \& Atkinson R.J., 2009. Pervasive threats within a protected area: conserving the endemic birds of São Tomé, West Africa. Animal Conservation, 12: 209-219. 
Dallimer M., Parnell M., Bicknell J.E. \& Melo M., 2012. The importance of novel and agricultural habitats for the avifauna of an oceanic island. Journal for Nature Conservation, 20: 191-199.

De Silva T.N., Townsend Peterson A., Bates J.M., Fernando S.W. \& Girard M.G., 2017. Phylogenetic relationships of weaverbirds (Aves: Ploceidae): A first robust phylogeny based on mitochondrial and nuclear markers. Molecular Phylogenetics \& Evolution, 109: 21-32.

De Silva T.N., Townsend Peterson A. \& Perktas U., 2019. An extensive molecular phylogeny of weaverbirds (Aves: Ploceidae) unveils broad nonmonophyly of traditional genera and new relationships. The Auk, 136: $1-21$

Fishpool L.D.C. \& Evans M.I.., 2001. Important Bird Areas of Africa and associated islands: Priority sites for conservation. Pisces Publications-BirdLife International, Newbury-Cambridge.

Gillespie R.G., Claridge E.M. \& Roderick G.K, 2008. Biodiversity dynamics in isolated island communities: interaction between natural and human-mediated processes. Molecular Ecology, 17: 45-57.

Glor R.E., 2011. Remarkable new evidence for island radiation in birds. Molecular Ecology, 20: 4823-4826.

Habib M.I., Hering J., Geiter O., Eilts H.-J., Megally M., Siegel S., Siegmund A. \& Winter M., 2018. The Yellow-billed Kite breeding at Nile Valley and Lake Nasser, Egypt, from 2012-2018: with notes on behaviour. Pernatye khishniki i ikh okhrana, 37: 230-238.

IUCN, 2021. Bostrychia bocagei. IUCN Red List of Threatened Species. Version 2020-3. On-line at: https://www.iucnredlist.org/species/22697478/13138 9052.

Johnson J.A., Watson R.T. \& Mindell D.P., 2015. Prioritizing species conservation: does the Cape Verde kite exist? Proceedings of the Royal Society B, Biological Sciences, 272(1570): 1365-1371.

Jones P.J. \& Tye A., 2006. The birds of São Tomé \& Príncipe with Annobón, islands of the Gulf of Guinea. B.O.U. Checklist Series 22, BOU-BOC, Oxford.
Jones P.J., Burlison P.J. \& Tye A., 1991. Conservação dos ecossistemas florestais na República Democrática de São Tomé e Príncipe. IUCN, Gland-Cambridge.

Lee D.-C., Halliday A.N., Fitton J.G. \& Poli G., 1994. Isotopic variations with distances and time in the volcanic islands of the Cameroon line: evidence for a mantle plume origin. Earth \& Planetary Science Letters, 123: 119-138.

Leventis A.P. \& Olmos F., 2009. As aves de São Tomé e Príncipe : um guia fotográfico. Aves \& Foto Editora, São Paulo.

Maia H., Gascoigne A., de Deus D. \& Lima R.F. de, 2014. Notes on the breeding ecology and conservation of the critically endangered Dwarf Olive Ibis Bostrychia bocagei. Bulletin of the African Bird Club, 21: 202-205.

Melo M. \& Fuchs J., 2008. Phylogenetic relationships of the Gulf of Guinea Alcedo kingfishers. Ibis, 150: 633-639.

Melo M., Warren B.H. \& Jones P.J., 2011. Rapid parallel evolution of aberrant traits in the diversification of the Gulf of Guinea white-eyes (Aves, Zosteropsidae). Molecular Ecology, 20: 4953-4967.

Naurois R. de, 1984. Prinia molleri Bocage, 1887, endémique de l'île de São Tomé. Rivista italiana di Ornitologia, 54: 191-206.

Olmos F. \& Turshak L.G., 2010. Bird observations from São Tomé: Monte Carmo as priority conservation site. Bulletin of the African Bird Club, 17: 54-65.

Pereira Azevedo F., 2015. Quantas galinholas Bostrychia bocagei existem em São Tomé? Uso do Distance Sampling e do Plot Sampling para estimar a população de uma ave endémica criticamente ameaçada. Master Dissertation, University of Évora.

Sargeant D.E., 1994. Recent ornithological observations from São Tomé and Príncipe islands. Bulletin of the African Bird Club, 1: 96-102.

Stattersfield A.J., Crosby M.J., Long A.J. \& Wiege D.C., 1998. Endemic Bird Areas of the World: Priorities for bird conservation. BirdLife International, Cambridge. 
. 